\section{FIFTIETH ANNIVERSARY CELEBRATIONS OF THE DISCOVERY OF RADIUM}

$\mathrm{T}$

HE fiftieth anniversary of the discovery of radium was celebrated, albeit two years late, by a series of meetings held at the Ecole Superieure de Physique et de Chimie de la Ville de Paris during July 16-20. The delay, engendered by post-war difficulties, was more than excused by the successful conduct of the occasion and the liberality of the hospitality extended to the wide circle of foreign men of science who were present.

The celebration began with a ceremony on July 16 at which Prof. L. de Broglie presided, attended on either side by the Curies' daughters, Irene and Eve. The audience was welcomed by the director of the college, Prof. R. Lucas, who paid tribute to the part played in the organisation of the function by $M$. G. Boreau, the president of the association of old students of the college, and by Prof. G. Champetier. Prof. de Broglie reviewed the scientific achievements of the Curie family, beginning with the earlier successes of Pierre Curie in the fields of piezo-electricity, the theory of crystal symmetry and of magnetism. The brilliantly successful, but all too short, period of collaboration with the Polish student, Marie Sklodowska, whom he married, was recalled, and the subsequent development of the science of radioactivity and the part played by their daughter Irene was briefly narrated. Prof. F. A. Paneth replied for the visitors, analysing the historical aspects of the discovery. M. Boreau, a student of the college during the years 1897-1900, welcomed delegates from scientific societies from all over the world and announced the receipt of telegrams from many others. Speeches were also delivered by Mme. Ferragi (Institut du Radium, Paris) and Prof. G. Champetier (Ecole Supérieure de Physique et de Chimie).

Following the ceremony, the audience attended the unveiling of a plaque, commemorating the discovery of radium by Pierre and Marie Curie with the assistance of Gustave Bemont, that had been affixed to the entrance to the college.

The delegates were entertained to a dinner on July 18, held on the first platform of the Eiffel Tower, and on the morning of July 20 many of them visited the laboratories of the Commissariat à l'Energie Atomique, which are at Fort Chatillon, just south of Paris.

The opening ceremony was followed by three colloquia, each lasting a day, during July 17-19. The first dealt with the formation of ions, excited molecules and radicals in liquids by ionizing radiations and with their distribution. F. A. Paneth (Durham) described work in progress in his laboratory on a new determination of the curie by measurement of the volume of helium formed in a measured time by a measured mass of radium in an aqueous solution of a radium salt. Lauriston Taylor (National Bureau of Standards, United States) reported some recent investigations with carbon disulphide, ligroin and other liquid-filled ionization chambers. L. H. Gray (London Hospital) reviewed the columnar theory of ionization, and, by the combination of this hypothesis with the freeradical hypothesis of indirect action in irradiated aqueous solutions, he drew conclusions as to the distribution and concentration of the radicals and the hydrogen and hydroxyl ions in irradiated aqueous solutions. Another aspect of this problem was con. sidered by F. S. Dainton (Cambridge), who showed how the kinetics of polymerization, induced by the irradiation of aqueous solutions of a monomer, will distinguish between uniform and non-uniform radical distribution. The session was concluded by a report of P. Jordan (Zurich) on the effects of mechanical recoil, following various neutron-induced nuclear reactions, when the irradiated material is in finely powdered form.

The second symposium was focused on the protection afforded by competitive reactions in irradiated media. N. L. Whitehead, C. Goodman and J. A. Breger (Massachusetts Institute of Technology), in a paper presented by the last-named author, discussed the decomposition of films of the fatty acids by the alpha. particles from radon and its relation to chain-length; the relevance of the investigation to the problem of the mode of formation of natural petroleum was briefly discussed. M. Burton described some results obtained in collaboration with $\mathrm{S}$. Gordon and R. R. Hentz (University of Notre Dame, Indiana), concerning the effect of alkyl substitution on the decomposition of benzene derivatives by X-radiation. A. Nightingale (Guy's Hospital, London) presented some preliminary results obtained by C. B. Allsopp (Guy's Hospital) on the X-and $\gamma$-irradiation of aqueous solutions of indole, and C. H. Collie and P. Shaw (Oxford) described the precautions necessary for the successful application of the Szilard-Chalmers concentration to the measurement of low neutron intensities by means of the alkyl halides. The morning session concluded with an analysis by $W$. Mund (Louvain) of the effects of ionizing radiations on the reaction between hydrogen and deuterium and the influence of foreign gases thereon.

The afternoon session was opened by a paper by M. Haissinsky and M. Lefort (Institut du Radium, Paris) on the effect of ionizing radiations on solutions of various oxidizing and reducing agents. Some effects in formic acid solution were described by A. H. W. Aten, jun. (Amsterdam), and J. Weiss (Durham) presented a variety of experimental results relating to effects in organic substances, particularly in aqueous solutions. F. H. Krenz (Edinburgh) discussed some theoretical aspects of the mechanism of indirect action in aqueous solutions. A. G. Maddock and J. H. Green (Cambridge) showed how the in. efficiency of bond rupture following radiative thermalneutron capture could be determined, and advanced a hypothesis explaining their results. The close analogy between the chemical effects of ionizing irradiations and ultrasonic irradiation of aqueous solutions was demonstrated by N. Miller (Edinburgh), and W. M. Dale (Manchester) emphasized the insufficiency of present physico-chemical hypotheses to explain the biochemical effect of ionizing radiation.

The third symposium concerned the production, prevention and recovery of radio-lesions. S. Rowlands (Edinburgh) described the irradiation of the stomach mucosa of dogs with phosphorus-32, and F. Ellis (London Hospital) compared the results of fractionation of X-irradiation of the skin. The mechanism of the action of ionizing radiations on yeast cells was examined by C. A. Tobias (Berkeley, California), and M. Lamarque (Montpellier) presented a study of the recovery of the eggs of the death's head moth following irradiation by X-rays. Z. M. Bacq, A. Herve and M. Betz (Liège) gave an account of the protective effect of sodium cyanide and azide.

The afternoon session opened with a paper by R. H. Mole (Atomic Energy Research Establish- 
ment, Harwell) on the possibility of protection, by chemical means, from whole-body irradiation. G. Hevesy (Stockholm) described some applications of tracers to the study of radio-lesions, and A. Forssberg (Stockholm) followed with a tracer study of the problem of protection from X-radiation. E. Lorenz (Bethesda, United States) presented a hæmatological study of the recovery of guinea pigs following chronic exposure to $\gamma$-radiation. The session closed with some further consideration of the problem of protection by L. F. Nims (Upton, United States).

A. G. MADDOCK

\section{SOUTH AFRICAN ASSOCIATION FOR THE ADVANCEMENT OF SCIENCE}

\section{ANNUAL CONGRESS}

S part of the diamond jubilee celebrations of
the foundation of Salisbury, Southern Rhodesia,
the congress of the South African Association
for the Advancement of Science was held there,
during July 3-7, in conjunction with the Rhodesia
Scientific Association. The meeting was most
successful, and was attended by more than one hun-
dred visitors from the Union as well as by men of
science from both the Rhodesias. The Sociedade de
Estudos, Mozambique, was also represented. Visitors
were well entertained by the town of Salisbury, by
the Grovernor and by the Rhodesia Scientific Associa-
tion, and a number of excursions were arranged
covering most of the varied interests of those present
at the congress.

In his presidential address to the Association, Prof. C. van Riet Lowe, director of the Union Archæological Survey, spoke on "Prehistory and the Humanities", making a plea for the wider teaching and study of prehistory as a means for emphasizing the essential unity of mankind and inducing a better appreciation of spiritual values.

The sectional address to Section A of the Association, by Mr. W. J. Jarvis, dealt with "Planning from a Multi-Racial Aspect" and considered some of the problems involved in integrating the native population into an introduced Western way of life. To Section B, Dr. A. M. Macgregor spoke on "The Primary Source of Gold", suggesting that gold mineralization is related to the intrusion of granitic material into basaltic rocks from which traces of gold are dissolved and concentrated. Dr. E. R. Roux spoke to Section C on "Interspecific Plant Hybrids" and cited examples of hybridization between apparently different genera which closer investigation shows might be merely very different adaptations; more studies on hybrids are needed. The address to Section D dealt with "Aspects of Museum Research", in which Mr. Reay H. N. Smithers, director of the National Museum, Bulawayo, showed the value of taxonomic studies in museums and urged the need for expansion of these services, which are basic to other biological researches. To Section E, Mr. Roger Summers, also of the National Museum, described "Iron Age Cultures in Southern Rhodesia", dealing particularly with the many ancient ruins and proposing a tentative chronology for them and for the Iron Age pottery found in the country.
Following the suggestion made by the United Nations Educational, Scientific and Cultural Organisation, a symposium was held on the theme of "Man's Use of Energy". An outstanding contribution was the first authoritative account of the plan to dam the waters of the Zambesi River at the Kareba Gorge, some two hundred miles below the Victoria Falls, and to set up power plants to develop about one million kVA. The dam would also make possible a big irrigation project.

Particular interest was aroused in the popular evening lecture-always a feature of the yearly congress-which this year was given by Dr. S. H. Skaife, of Cape Town, and included a colour film showing the activities of termites which he has kept for fifteen years in specially designed and constructed nests. The life-cycle of the insects was traced, and many new sidelights thrown on the totalitarian regime of these creatures, which were seen on the screen at very large magnifications.

\section{THE NATURALIST IN THE FIELD TO-DAY}

$\mathrm{T}$

HE Nature Conservancy is now in being and is a potential check against the destruction of areas in Great Britain of special importance from the point of view of geological structure, vegetation or other wild life, or of scenic beauty. The widespread seizure of these areas for afforestation, agriculture, Service requirements, etc., makes it all the more imperative to preserve what is left. But reserves can never be administered effectively by remote committees-still less from a 'window in Whitehall'. The care and vigilance of local interests, and especially of local naturalists, is needed: How far are they competent to shoulder this responsibility? This question formed the subject of the presidential address by Dr. E. A. R. Ennion to the Conference of Delegates of Corresponding Societies at the recent meeting at Birmingham of the British Association.

Dr. Ennion, as warden of Flatford Mill Field Centre, has devoted the past five years to devising ways and means whereby the 'amateur naturalist', irrespective of age, sex, background or calling, can gain increasing competence in his or her special interests. The experimental stage is almost ended.

There has been a steady rise, growing steeper in post-war years, in the 'curve of opportunity' open to the amateur naturalist. Dr. Ennion discussed some of the contributory factors in turn: books and journals ; natural history society reports ; lectures, with the improved technique now offered by various visual aids ; films; broadcasts. But all these have one fundamental weakness-the recording of someone else's triumphs and experiences. Only by personal exertions and discoveries is anyone really able to become a naturalist.

The opportunities for first-hand experience and guidance in field-work have increased considerably, although mainly for two groups: the university student, who has facilities especially for marine work at Plymouth, Millport, Port Erin, etc.; and the ornithologist, at any of the small coastal bird observatories, Skokholm, Lundy, Spurn Head, etc. A trend towards establishing inland stations is growing, too: Oxford at Wytham; Cambridge at Madingley ; and the narrow boat Beatrice of the Severn Wildfow] Trust are instances in point. 